Reprod. Nutr. Dévelop., 1981, 21 (6A), 901-917.

\title{
Behaviour of digestive enzymes in the pancreatic juice and pancreas of rats fed on a low-protein diet ( 3 p. 100 of cereal protein) then on a balanced diet (23.5 p. 100 of mixed protein)
}

par O. KHEROUA, J. BELLEVILLE *

\author{
Laboratoire de Physiologie de la Nutrition \\ Universifé d'Oran, Algérie. \\ * Laboratoire de Physiologie de la Nutrition \\ UER Nutrition, BP 138, 21100 Dijon Cedex, France.
}

Summary. The aim of this study in the rat was to determine the effect of a low-protein diet ( 3 p. 100 cereal protein) and balanced refeeding ( 23.5 p. 100 mixed protein) on the activity of some pancreatic digestive enzymes and the amount of their secretion. Parrallel studies were carried out on the pancreas and its exocrine secretion.

1) With a low-protein diet (21 days), there was a decrease in the amounts of bile and pancreatic juice secrefed. During balanced refeeding (18 days), the amount of bile secreted returned to normal and, although that of the juice increased, it was less than the amount secreted by the reference lot.

2) Body and pancreatic weights decreased slightly with the low-protein diet. The protein content and mitotic ability of the pancreas declined. However, during balanced refeeding, the ponderal weight of the pancreas returned to normal more rapidly than that of the overall organism. Pancreatic protein content and mitotic ability also augmented.

3) The low-protein diet produced an overall decrease in enzyme activity in the pancreas and in the juice. However, in the absence of any diefary stimulation, these activities were not affected proportionally in the same way as the pancreas and its exocrine secretion. Nevertheless, no disturbance in the digestion and absorption of the ration was observed.

4) During balanced refeeding, enzyme activities increased to different levels in the juice and the pancreas but after 18 days total enzyme activity had not been entirely recovered.

5) Enzyme activity varied widely, especially during the first $48 \mathrm{hrs}$ of malnutrition and the first 36 hrs of refeeding.

\section{Introduction.}

Protein deficiency causes serious disorders in the pancreas. It is important for pediatricians to know what ability protein-deficient children have to digest a wellbalanced diet when they are refed after protein malnutrition. Digestive enzyme activities are usually lower in the duodenal aspirates of human infants (Gomez et al., 1954 ; Barbezat, 1967 ; Tandon ef al., 1969 ; Danus et al., 1970 ; Pitchumoni, 1973 ; Watson ef al., 1977) when their diet is protein-deficient. However, since low-protein diets and the length and seriousness of malnutrition vary in humans, the results reported by various authors are also divergent. Moreover, for obvious reasons, the chronology of 
the impact of malnutrition on these activities cannot be studied in humans. It is therefore necessary, in clinical studies on children, to carry out parallel studies in the rat which is a good animal model for this type of research (Sroboda, Grady, Higginson, 1966 ; Heard, Frangi, Wright, 1977).

Authors studying rats with different protein deficiencies found diverse qualitative and quantitative variations as to the decrease in enzyme activity (Lyman and Wilcox, 1963 ; Vandermeers et al., 1964, 1966, 1967a, b, 1968 ; Robberecht et al., 1967 ; Lemire and Iber, 1969 ; Kopec, Bucko, and Babala, 1972). Some of these contradictions arise because the profile of enzyme activity is not linear in relation to the length of malnutrition or refeeding. To clarify this question, we studied rats fed on a low-protein diet similar to that of humans so that any chronological changes in pancreatic digestive enzyme behaviour would become evident. It was also necessary to carry out a parallel study on the pancreas and pancreatic juice to determine if these changes affected enzyme synthesis and/or excretion. Our aim was to answer the following questions :

1) are the digestive enzyme activities in the juice and in the pancreas parallel during malnutrition and refeeding ?

2) are the pancreatic digestive activities affected enough to exacerbate malnutrition and disturb refeeding?

\section{Material and methods.}

I. Animals and diets. -108 female Wistar rats weighing $175 \pm 5 \mathrm{~g}$ at the beginning of the experiment were divided into two equal lots. A reference lot ( $T$ ) was fed on a balanced diet for 39 days containing 23.5 p. 100 mixed protein. A deficient lot (E) was fed on a low-protein diet ( 3 p. 100 cereal protein) for 21 days (phase I : malnutrition), then on a balanced diet for 18 days (phase II : refeeding). Table 1 shows the ponderal and energetic compositions of both diets which were isocaloric.

TABLE 1

Dief compositions in ponderal and energetic percentages

\begin{tabular}{|c|c|c|c|c|c|c|c|c|c|}
\hline \multirow{2}{*}{ Diet } & \multicolumn{2}{|c|}{ Protein } & \multicolumn{2}{|c|}{ Lipid } & \multicolumn{2}{|c|}{ Carbohydrates } & \multirow{2}{*}{$\begin{array}{c}\begin{array}{c}\text { Minerals } \\
+ \\
\text { vitamins }\end{array} \\
\begin{array}{c}\text { p. } 100 \\
\text { ponderal }\end{array}\end{array}$} & \multirow{2}{*}{$\begin{array}{c}\text { Cellulose } \\
\begin{array}{c}\text { p. } 100 \\
\text { ponderal }\end{array}\end{array}$} & \multirow{2}{*}{$\begin{array}{c}\mathrm{kJ} / 100 \mathrm{~g} \\
\text { of diet }\end{array}$} \\
\hline & $\begin{array}{c}\text { p. } 100 \\
\text { ponderal }\end{array}$ & $\begin{array}{c}\text { p. } 100 \\
\text { energetic }\end{array}$ & $\begin{array}{c}\text { p. } 100 \\
\text { ponderal }\end{array}$ & $\begin{array}{c}\text { p. } 100 \\
\text { energetic }\end{array}$ & $\begin{array}{c}\text { p. } 100 \\
\text { ponderal }\end{array}$ & $\begin{array}{c}\text { p. } 100 \\
\text { energetic }\end{array}$ & & & \\
\hline Reference... & 23.5 & 25 & 5 & 12 & 59.5 & 63 & 8 & 5 & 1577 \\
\hline Low protein & 3 & 3.2 & 5 & 12 & 80 & 84.8 & 8 & 4 & 1577 \\
\hline
\end{tabular}

The animals, kept at $25^{\circ} \mathrm{C}$, ate and drank ad libitum. They were weighed every 2 days and the amount of their intake was determined daily.

II. Samples of pancreatic juice and pancreas. - We used pools of 3 animals each for every sample of pancreatic juice and pancreas in each lot. The chronology of the sampling was : phase I : malnutrition - days 1, 2, 9, 15, 21 ; phase II : refeeding - days $1,6,12,18$. 
1. Collection of pancreatic juice. - The 3 rats used for one sampling underwent surgery between 9 and 10 a.m. We fitted a double pancreato-bile duct cannula according to the technique of Colwell (1951), allowing us to obtain pure juice with no bile. During the whole sampling period, the rats were fasted but drank water freely. The first drops of juice obtained from the cannula were eliminated since they contained active trypsin from surgical lesions in the duct cells. The juice thus collected at $0{ }^{\circ} \mathrm{C}$ for $48 \mathrm{~h}$ had no active trypsin and was constantly rich in enzymes, as reported by Reboud, BenAbdeljlil and Desnuelle (1961). During the sampling period, no bile or juice was reintroduced into the intestinal aperture. To avoid successive freezing and thawing, the juice from 3 rats was pooled and stored at $-25^{\circ} \mathrm{C}$ in the form of aliquot parts, each one to be used for a particular test.

2. Sampling of pancreatic extracts. - After one night of fasting, the rats were always killed between 11 a.m. and noon by breaking their necks. The pancreatic samples were accurately standardized. After weighing, the 3 pancreata of each of the two lots were ground together in distilled water $(1 \mathrm{ml} / 100 \mathrm{mg}$ of fresh tissue). Tests were then effected directly on the ground material, preserved in the same conditions as the juice.

III. Determination of the nitrogen balance. - Three cumulative nitrogen balances were carried out on 6 rats from the reference lot and on 6 rats which had been fed on a low-protein diet and then refed on a balanced diet for the first six days (balance 1) and the last six days (balance 2) of phase I, then for the first six days (balance 3) of phase II.

The nitrogen balance was given by the formula :

$$
\frac{N \text { ingested }-N \text { excreted (urine and faeces) }}{N \text { ingested }} \times 100 \text {. }
$$

Each of these parameters, measured for the duration of each balance, allowed us to calculate the coefficient of digestive utilisation of nitrogen (CDU)

$$
\frac{\mathrm{CDU}=\mathrm{N} \text { ingested }-\mathrm{N} \text { excreled (faeces) }}{\mathrm{N} \text { ingested }} \times 100 \text {. }
$$

IV. Testing technique. - Protein was tested according to the technique of Lowry ef al. (1951). We used beef albumin serum in plotting the reference curve. The nucleic acids were measured using Munro and Fleck's technique (1966). Except for amylase, all the enzyme activities were tested by titrimetry using a $\mathrm{pH}$ stat Radiometer on specific substrates. Chymotrypsin activity was determined by measuring the hydrolysis of the $\mathrm{N}$-acetyl-L-tyrosin ethyl ester monohydrate and that of trypsin by degradation of the $\mathrm{N}$-benzoyl-L-arginine ethyl ester hydrochloride after activation of the pro-enzyme forms by the exogenous trypsin using the method of Figarella, Taulier and Sarles (1965). Lipasic activity was tested with the technique of Borgström and Hildebrand (1975). We tested potential lipase activity on a tributyrin substrate since the incubation medium had no bile salts. Phospholipase $A_{2}$ was measured according to de Haas et al. (1968) using an egg yolk extract as substrate. Only amylase activity was tested with a spectrophotometric technique (Metais and Bieth, 1968), starch being the hydrolysed substrate. 


\section{Results.}

I. Animal weight and dietary intake (fig. 1). - The weight of deficient rats dropped at the beginning of phase $I$ and then stabilized. The reference lot grew constantly throughout the experiment. After 21 days of a low-protein diet, the mean weight of the deficient animals was 70 p. 100 of that of the reference lot.

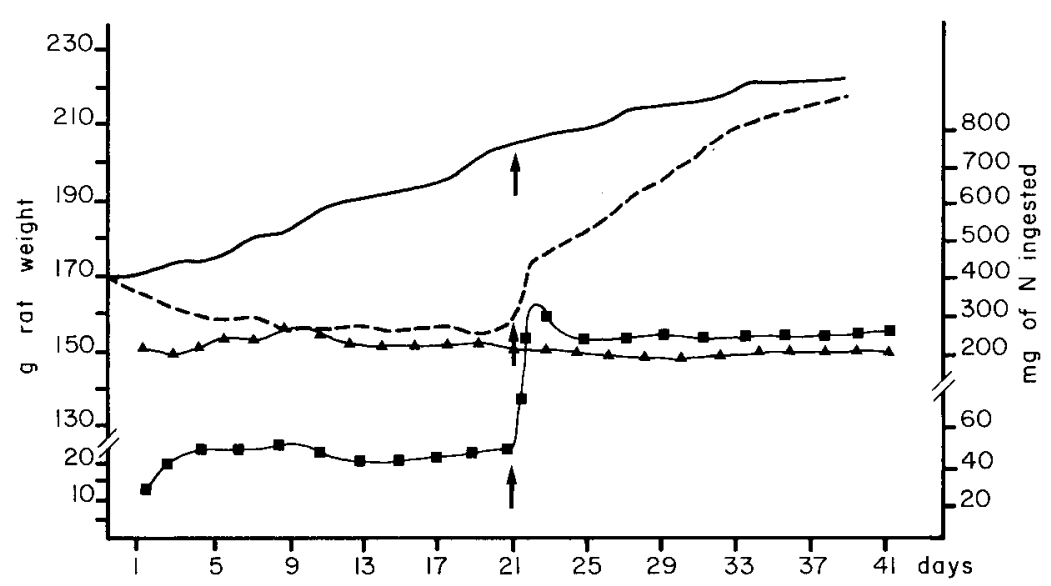

FIG. 1. - Animal weight and amount of $N$-intake $/$ day $/ 100 \mathrm{~g}$ of body weight.

-reference rat weight ; -..- weight of deficient-refed rats ; $\Delta-\Delta \mathrm{N}$-intake/day/100 $\mathrm{g}$ of reterence rat weight; -- $\mathrm{N}$-intake/day $/ 100 \mathrm{~g}$ of weight in deficient-refed rats $; \hat{\uparrow}$ end of malnutrition and beginning of balanced refeeding in low-protein diet rats.

On refeeding, the weight of the deficient animals increased rapidly and strongly ; the slope of the growth curve then lessened but was still greater than that of the reference lot. After 21 days of balanced refeeding, their weight equalled 96 p. 100 of that of the reference lot.

In deficient rats, the intake/rat/day stayed at about $14 \mathrm{~g}$ during all of phase $\mathrm{I}$. In the reference lot, that intake increased regularly from $14 \mathrm{~g}$ at the beginning of the experiment to $20 \mathrm{~g}$ at the end. When the rats were refed, they ate $19 \mathrm{~g}$ during the first $48 \mathrm{~h}$ and their intake remained slightly higher than that of the reference lot throughout phase II. However, when this intake was expressed in $100 \mathrm{~g}$ of weight/day, both lots ate about the same amount throughout the experiment $(8.5$ to $9 \mathrm{~g})$.

On the contrary, $\mathrm{N}$-intake/rat/day was considerably different in the two lots. During phase I, the deficient rats ate only about 11 p. 100 of the amount of $N$ ingested by the reference lot, whereas during phase II the $\mathrm{N}$-intake of refed animals was 10 p. 100 higher than that of the reference lot. The amount of $N$ ingested $/ 100 \mathrm{mg}$ of body weight/day (fig. 1) by the deficient rats was only 14 p. 100 of that of the reference lot. When the animals were refed, that percentage rose to 15 .

In the deficient rats, the nitrogen balance was negative at the beginning of malnutrition ( -4 p. 100) and slightly positive at the end $(+5.4$ p. 100), whereas the CDU ranged between 62 and 66 p. 100 in comparison with $82-85$ p. 100 in the reference lot (table 2). 
TABLE 2

Cumulative nitrogen balance and coefficient of digestive utilisation (CDU) of proteins during phase I (balances 1 and 2) and phase II (balance 3)

\begin{tabular}{|c|c|c|c|c|c|c|c|c|}
\hline & Lot & $\begin{array}{l}\text { Dietary N } \\
\text { ingested/rat/ } \\
6 \text { days } \\
\text { (g) }\end{array}$ & $\begin{array}{c}\text { Faecal N/rat/ } \\
6 \text { days } \\
(g)\end{array}$ & $\begin{array}{l}\text { p. } 100 \text { of faecal } \\
N \text { in relation } \\
\text { to } N \text { ingested }\end{array}$ & $\begin{array}{l}\text { Urinary } \\
\text { N/rat/ } \\
6 \text { days }\end{array}$ & $\begin{array}{l}\text { p. } 100 \text { of urinary } \\
N \text { in relation } \\
\text { to } N \text { ingested }\end{array}$ & $\begin{array}{l}\text { Cumulative } \\
\text { nitrogen } \\
\text { balance } \\
\text { (p. 100) }\end{array}$ & $\begin{array}{c}\text { CDU } \\
(p .100)\end{array}$ \\
\hline \multirow{2}{*}{$\begin{array}{l}\text { Balance } 1 \\
\text { from } 1 s^{t} \\
\text { to } 6 \text { th day } \\
\text { of phasel }\end{array}$} & $\mathrm{T}$ & 2.83 & 0.51 & 18 & 0.94 & 33 & 49 & 82 \\
\hline & $E$ & 0.35 & 0.134 & 38 & 0.23 & 66 & -4 & 62 \\
\hline \multirow{2}{*}{$\begin{array}{c}\text { Balance } 2 \\
\text { from } 15 \text { th } \\
\text { to } 21 \text { st day } \\
\text { of phase } 1\end{array}$} & $T$ & 3.2 & 0.48 & 15 & 1.22 & 38 & 47 & 85 \\
\hline & $E$ & 0.37 & 0.126 & 34 & 0.224 & 60 & 5.4 & 66 \\
\hline \multirow{2}{*}{$\begin{array}{l}\text { Balance } 3 \\
\text { from 1st } \\
\text { to 6th day } \\
\text { of phase II }\end{array}$} & $T$ & 3.13 & 0.448 & 14.3 & 0.985 & 31 & 54 & 86 \\
\hline & $E$ & 3.16 & 0.38 & 12 & 0.683 & 21 & 67 & 88 \\
\hline
\end{tabular}

II. Weight and DNA and RNA protein contents of the pancreas (fig. 2, 3). - While pancreatic weight increased with time in the reference lot, it remained stable in the deficient rats and, at the end of phase l, was only 72 p. 100 of that of the reference lot.
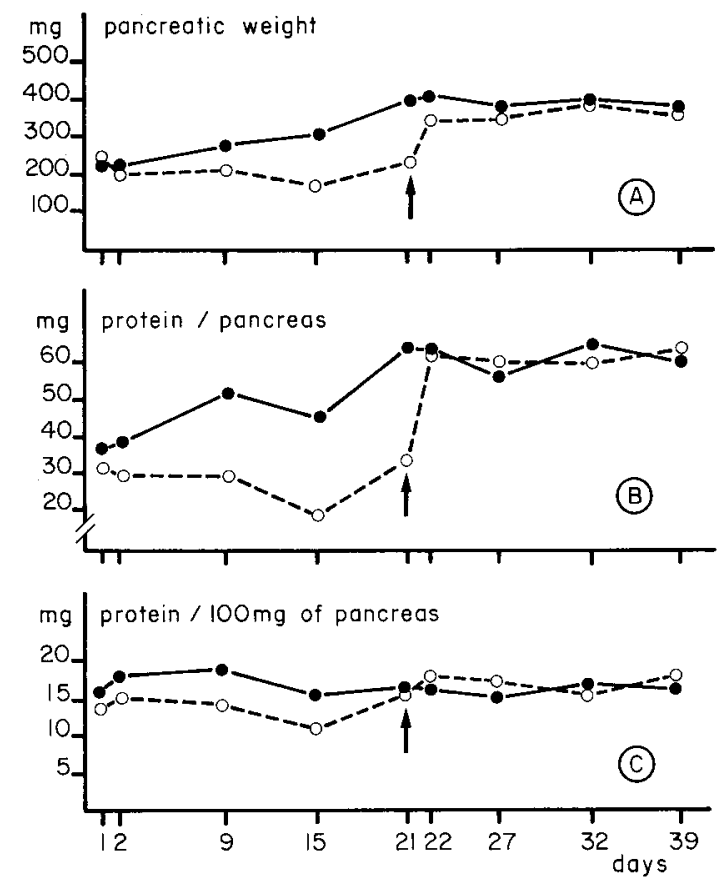

FIG. 2. - Mean weight, amount and protein content of the pancreas.

$\bullet-$ reference rats ; o-... o deficient-refed rats. 

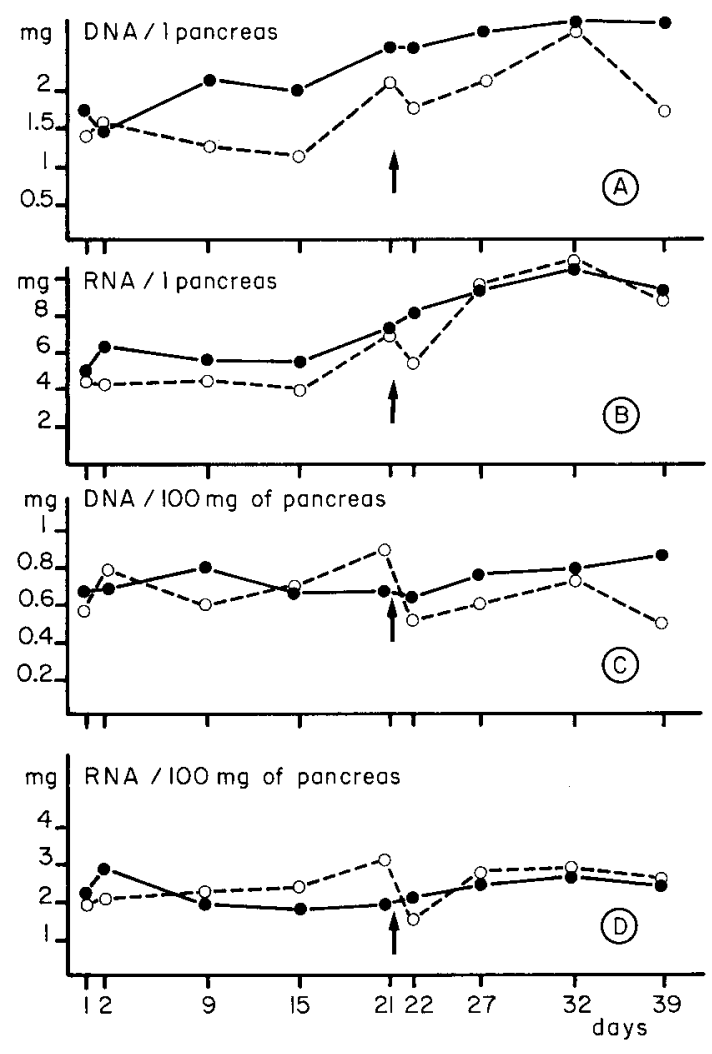

FIG. 3. - Pancreatic DNA and RNA content.

-- - reference rats; o-.--o deficient-refed rats.

During phase II, pancreatic weight returned to normal quicker than body weight. The weight of the pancreas related to body weight was not significantly lower in the deficient rats during phase I and was slightly higher during phase II. The amount of protein $/ 1$ pancreas decreased by 37 p. 100 for the whole of phase I, whereas when expressed in units of pancreatic weight, it declined by only 17 p. 100. Here again during phase II, the values returned quickly to those of the reference lot.

DNA/1 pancreas was 25 p. 100 lower in deficient rats, but when expressed in units of pancreatic weight, it was comparable in both lots. These two values were signifificantly lower in refed animals during phase II.

RNA/1 pancreas only decreased by 11 p. 100 during the whole of phase 1 ; when expressed in $100 \mathrm{mg}$ of pancreas, the values were similar in both lots of rats. Phase II showed similar values for these parameters in the refed rats and the reference lot.

III. Amounts of bile, pancreatic juice and juice protein secreted (fig. 4). - Biliary and pancreatic secretions were produced in the absence of any dietary stimulation, for our animals were fasted. Those secretions can therefore be considered as basic. Moreover, 

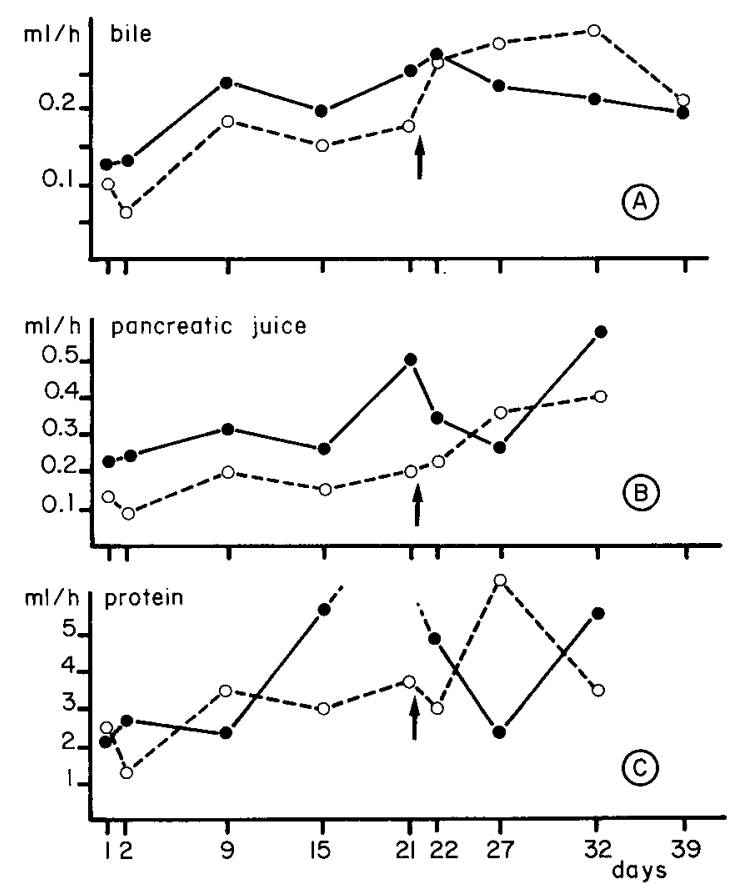

FIG. 4. - Amounts of bile, pancreotic juice and juice protein secrefed.

-- reference rats; $0 .-$-o deficient-refed rats.

the fact that no secretions were reintroduced into the intestinal aperture caused us to diverge from normal conditions. This point will be discussed later. However, the results on the animals in both lots may be compared for they were obtained in the same sampling conditions.

During malnutrition, the amount of bile secreted by deficient rats generally decreased by 26 p. 100 , that of juice by 51 p. 100 and that of protein by 36 p. 100, even though the juice protein content increased by 38 p. 100 . During phase ll, the amount of bile secreted by refed rats rose more than 21 p. 100 , while the amounts of juice and protein secreted were similar in both lots.

IV. Enzyme activities. - Specific activities (SA) of trypsin and chymotrypsin were expressed in $\mu \mathrm{Eq}$ of amino acids released $/ \mathrm{min} / \mathrm{mg}$ of protein, those of lipase and phospholipase $\mathrm{A}_{2}$ in $\mu \mathrm{Eq}$ of fatty acids released $/ \mathrm{min} / \mathrm{mg}$ of protein, and that of amylase in $\mu \mathrm{Eq}$ of hydrolysed starch $/ \mathrm{min} / \mathrm{mg}$ of protein.

Total pancreatic activities (TA) were obtained by multiplying the SA of the enzyme by the quantity of proteins contained in one pancreas. The TA/100 mg, enabling us to determine the activity of the enzyme in relation to the unit of gland weight, was obtained by multiplying the SA of the enzyme by the quantity of protein in $100 \mathrm{mg}$ of pancreas.

The amount of juice secreted was calculated by multiplying the SA of the enzyme by the amount of protein secreted/h.

For the different enzyme activities we compared the results measured in the refed- 
deficient rats with those of the reference lot. The statistical significance of the differences observed in pancreas extract activities is given in table 3 ; table 4 shows the statistical significance of differences in pancreatic juice activities.

TABLE 3

Mean enzyme activity values of the pancreata of deficient or refed rats compared with the reference values over the entire periods of malnutrition and refeeding

\begin{tabular}{cccccc}
\hline & Malnutrition & \multicolumn{3}{c}{ Refeeding } \\
\hline $\begin{array}{c}\text { SA } \\
(\mathrm{p} .100)\end{array}$ & $\begin{array}{c}\text { TA } \\
(\mathrm{p} .100)\end{array}$ & $\begin{array}{c}\text { TA/100 mg } \\
\text { of pancreas } \\
\text { (p. 100) }\end{array}$ & $\begin{array}{c}\text { SA } \\
(\mathrm{p} .100)\end{array}$ & $\begin{array}{c}\text { TA } \\
(\mathrm{p} .100)\end{array}$ & $\begin{array}{c}\text { TA } 100 \mathrm{mg} \\
\text { of pancreas } \\
(\mathrm{p} .100)\end{array}$ \\
\hline$-24.5^{*}$ & $-52.5^{* *}$ & $-39^{* * *}$ & $-25^{*}$ & $-25^{*}$ & $-19 \mathrm{NS}$ \\
\hline$-35^{* * *}$ & $-60^{* * *}$ & $-47.5^{* * *}$ & $+13 \mathrm{NS}$ & $+13 \mathrm{NS}$ & $+23 \mathrm{NS}$ \\
\hline$-18.5^{*}$ & $-48^{* * *}$ & $-31^{*}$ & $+6 \mathrm{NS}$ & $+9 \mathrm{NS}$ & $+9 \mathrm{NS}$ \\
\hline$-25^{*} \mathrm{NS}$ & $-54.5^{* * *}$ & $-41^{* *}$ & $+1.5 \mathrm{NS}$ & $-11.5 \mathrm{NS}$ & $+10 \mathrm{NS}$ \\
\hline$-61^{* * *}$ & $-75^{* *}$ & $-68^{* * *}$ & $-7.5 \mathrm{NS}$ & $-3 \mathrm{NS}$ & $-7.5 \mathrm{NS}$ \\
\hline
\end{tabular}

${ }^{*} \mathrm{P}<0.05 ;{ }^{* *} \mathrm{P}<0.02 ;{ }^{* *} \mathrm{P}<0.01$; NS : non-significant.

TABLE 4

Mean enzyme activity values of the pancreatic juice of deficient or refed rats compared with the reference values over the entire periods of malnutrition and refeeding

\begin{tabular}{|c|c|c|c|c|}
\hline & \multicolumn{2}{|c|}{ Malnutrition } & \multicolumn{2}{|c|}{ Refeeding } \\
\hline & SA (p. 100) & $\begin{array}{l}\text { Amount } \\
\text { secreted/h } \\
\text { (p. 100) }\end{array}$ & SA (p. 100) & $\begin{array}{c}\text { Amount } \\
\text { secreted/h } \\
\text { (p. 100) }\end{array}$ \\
\hline Trypsin & -21 NS & -32 NS & +18 NS & $+13.5 \mathrm{NS}$ \\
\hline Chymotrypsin .... & $-30^{* * *}$ & $-56.5^{*}$ & +24 NS & +27 NS \\
\hline Lipase ......... & $-58^{* * *}$ & $-71.5^{*}$ & $-22.5 \mathrm{NS}$ & $-23 N S$ \\
\hline Phospholipase $\mathrm{A}_{2}$. & $-76^{*}$ & $-76^{*}$ & $-42^{*}$ & $-42 *$ \\
\hline Amylase ....... & $-64.5^{* *}$ & $-90.5^{* * *}$ & $-47^{*}$ & $-41^{*}$ \\
\hline
\end{tabular}

${ }^{*} \mathrm{P}<0.05 ;{ }^{* *} \mathrm{P}<0.02 ;{ }^{* *} \mathrm{P}<0.01$; NS : non-significant.

1. Trypsin (fig. 5, 6). - Throughout phase I, SA was 25 p. 100 less in the pancreas and 21 p. 100 less in the juice. It should be noted that the SA in the juice of deficient rats was higher than that of the reference lot before the end of malnutrition. The total activity (TA), TA/100 mg and amount secreted were even more affected because they declined by 52,39 and 32 p. 100 , respectively. 

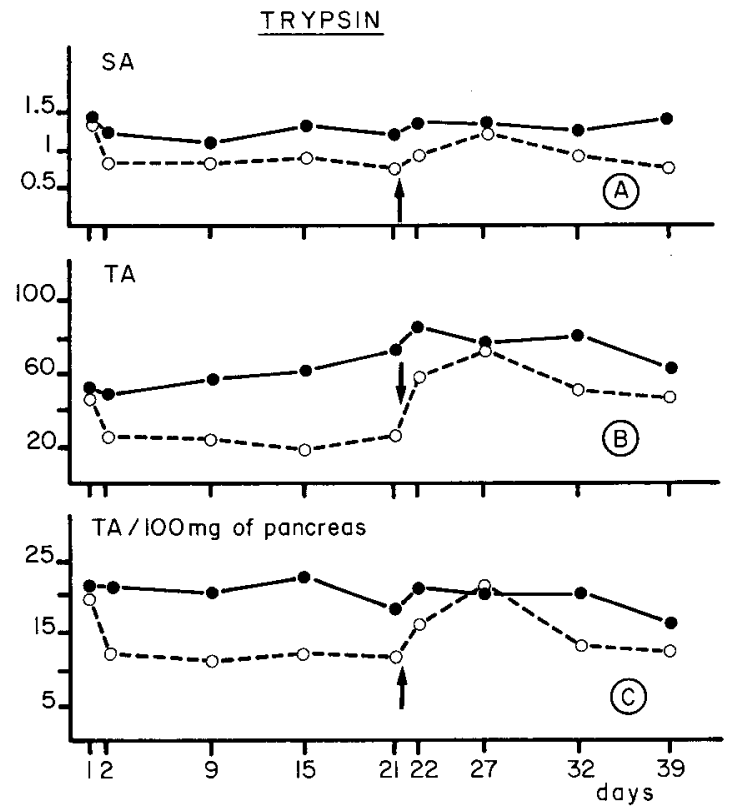

FIG. 5. - Pancreatic trypsin octivity.

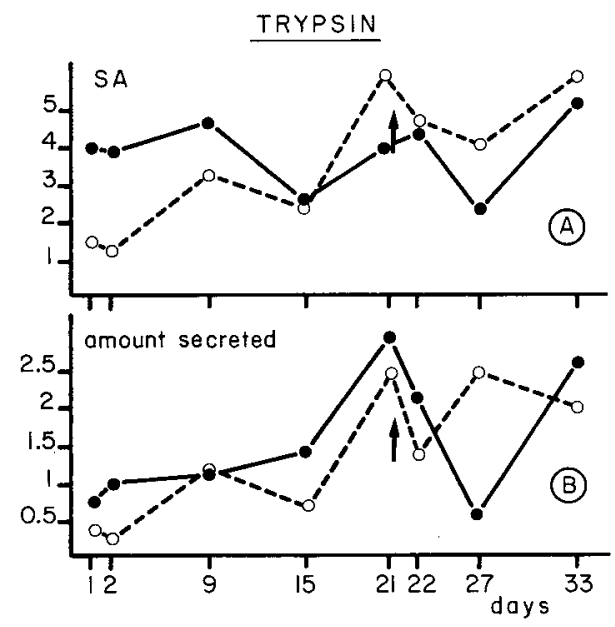

FIG. 6. - Pancreatic juice trypsin activity.

Amount secreted : amount of enzyme secreted $=S A \times$ amount of protein secreted in the juice/h. - - reference rats ; o---o deficient-refed rats ; $\mathrm{SA}$ : specific activity expressed in $\mu \mathrm{Eq}$ of substrate hydrolyzed $/ \mathrm{min} / \mathrm{mg}$ of protein ; TA : total pancreatic enzyme activity : SA $\times$ protein content $(\mathrm{mg}) / 1$ pancreas ; TA/100 $\mathrm{mg}$ of pancreas : SA $\times$ protein content/100 $\mathrm{mg}$ of pancreas.

SA in the pancreas did not increase during phase II ; it even dropped in the juice at first. TA and TA/100 mg were definitely improved but remained 25 and 19 p. 100 less, 
respectively, than the reference values, while the amount secreted/h was usually 14 p. 100 higher.

Trypsin activity was lower in the pancreas of the refed rats, but higher than that of the reference lot in the juice.

2. Chymotrypsin (fig. 7, 8). - SA of the pancreas and the juice were 35 and 32 p. 100 lower, respectively, during phase 1 . The same was true for TA, TA/100 $\mathrm{mg}$ and amount secreted/h, which declined by 60,48 and 57 p. 100. This enzyme was more responsive to malnutrition than the previous enzyme.

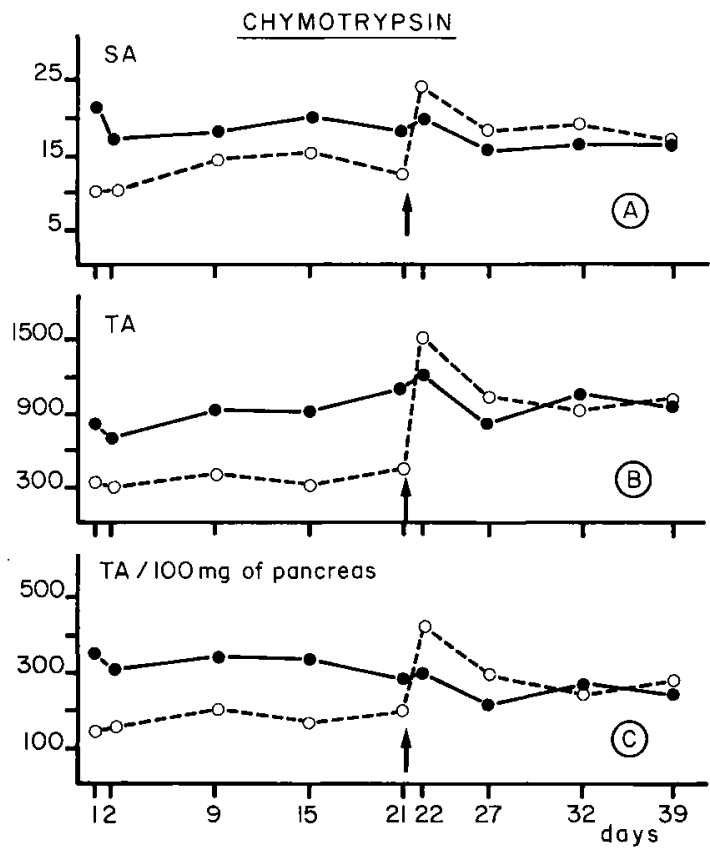

FIG. 7. - Pancrealic chymotrypsin activity (legend fig. 5).
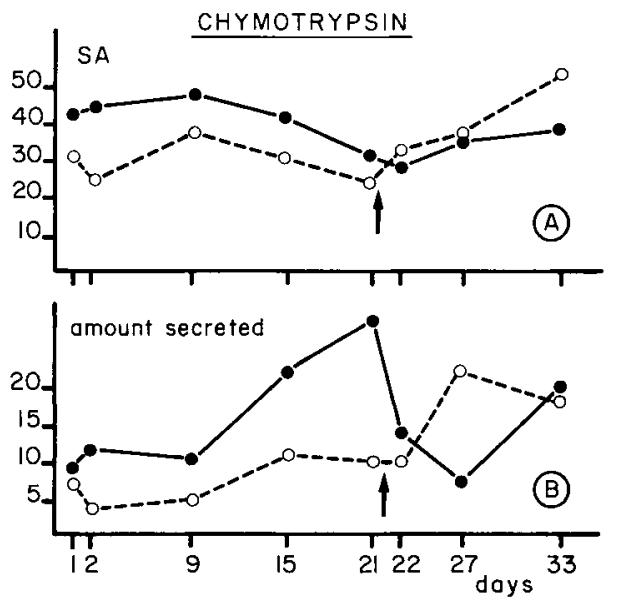

FIG. 8. - Pancreatic juice chymotrypsin activity (legend fig. 6).

In the first $24 \mathrm{~h}$, refeeding caused a considerable increase in pancreatic activity, whereas in the juice that activity increased gradually. During the whole of phase II, the SA increased 13 p. 100 in the pancreas and 24 p. 100 in the juice. TA, TA/100 mg and the amount secreted/h increased by 13,23 and 27 p. 100, respectively. Chymotrypsin thus showed good recovery in the juice as well as in the pancreas.

3. Lipase (fig. 9, 10). - SA decreased by 58 p. 100 in the juice during phase I and $18 \mathrm{p} .100$ in the pancreas. TA, TA/100 mg and amount secreted/h also decreased in the deficient rats by 48,31 and 72 p. 100 , respectively.

During phase II, SA, TA and TA/100 mg were very similar in both lots of rats. In the juice, although SA rose at the beginning of phase II, it remained lower $(-22.5$ p. 100) than the reference values, while the amount secreted returned to normal sooner. 

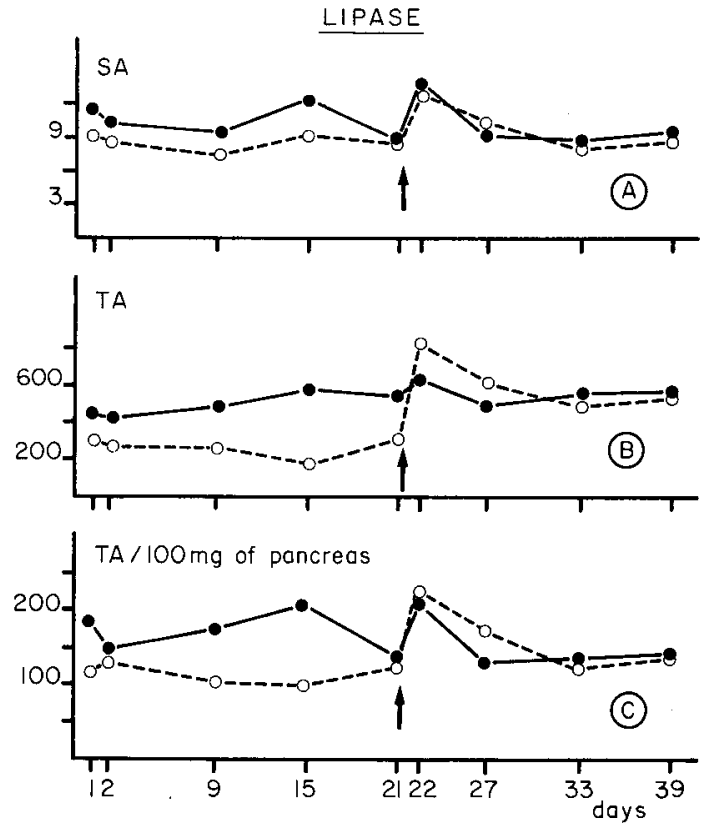

FIG. 9. - Pancreatic lipase activity (legend fig. 5).

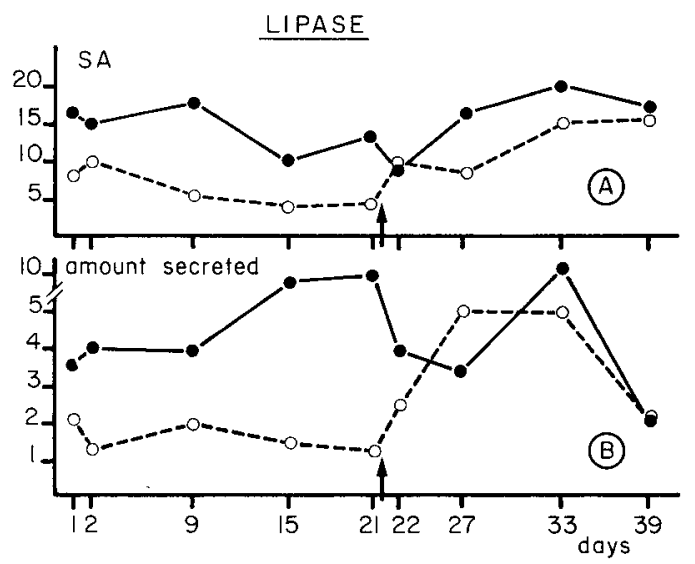

FIG. 10. - Pancreatic juice lipose activity (legend fig. 6).

4. Phospholipase $A_{2}$ (fig. 11, 12). - The SA of this enzyme, as that of lipase, was more affected in the juice (-76 p. 100) than in the pancreas ( -26 p. 100). TA, TA/100 mg and the amount secreted/h confirm these results because they declined by $54.5,41$ and 76 p. 100 , respectively. It should be noted that results on the reference juice were very dispersed. In spite of that, the values of deficient rats were always lower than those of 

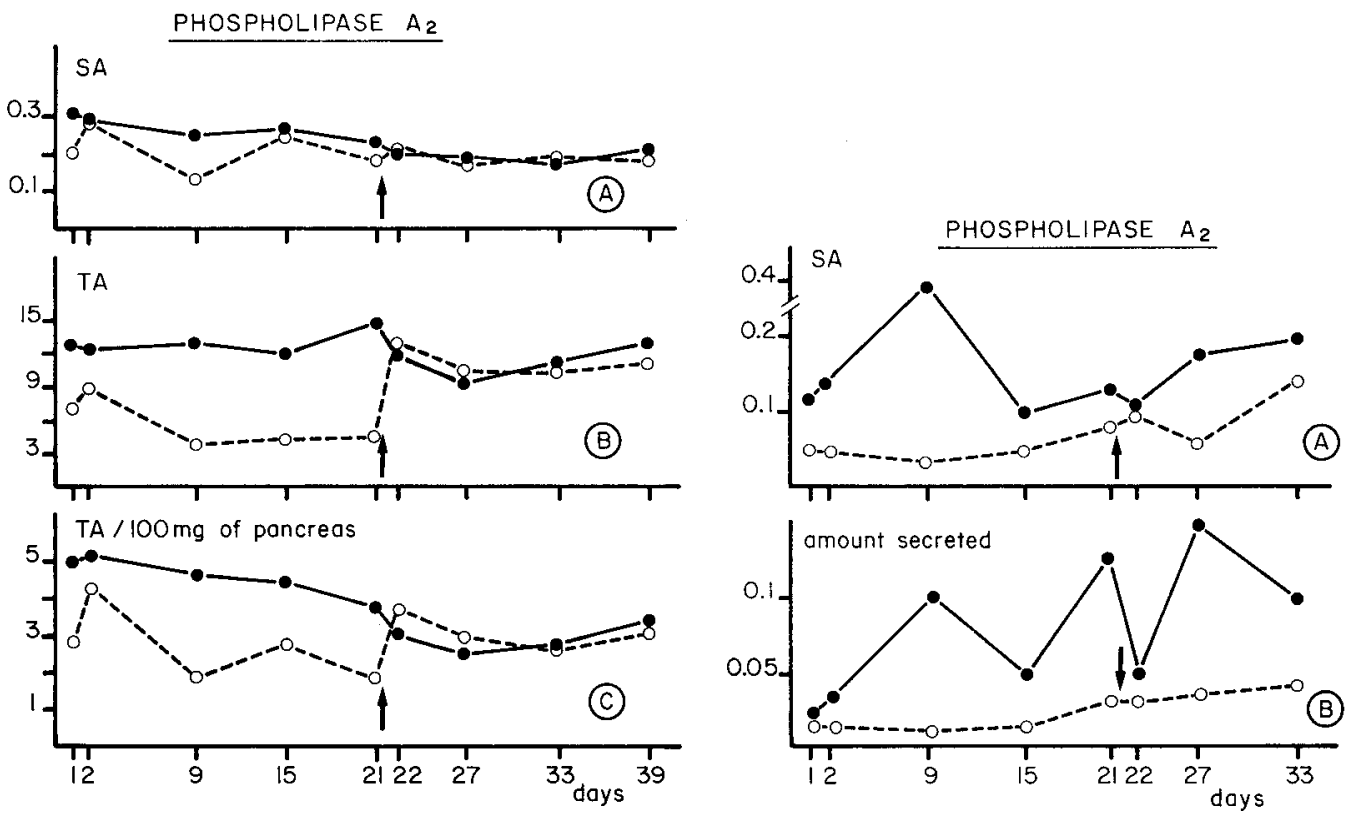

FIG. 11. - Pancreatic phospholipase $A_{2}$ activity (legend fig. 5).

FIG. 12. - Pancreatic juice phospholipase $A_{2}$ activity (legend fig. 6).

the reference lot. During refeeding, enzyme activity returned quickly to normal in the pancreas, while in the juice, SA and the amount secreted/h usually represented only 42 p. 100 of the reference values. Thus, as for lipase, but in a more marked way, there was a quick return to normal in the pancreas while malnutrition disorders persisted in the juice.

5. Amylase (fig. 13, 14). - This enzyme was the one most affected by malnutrition. SA in the pancreas decreased by 61 p. 100 , TA by 75 p. 100 and TA/100 mg by 68 p. 100. In the juice, $S A$ resisted for the first 2 days, then enzyme activity almost disappeared. After refeeding, the values returned rapidly to normal in the pancreas, while in the juice, the $S A$ was still deficient after 18 days, and during the entire phase Il the values of refed rats were less than those of the reference lot $(-47$ p. 100 for SA ; -41 p. 100 for amount secreted/h).

\section{Discussion.}

The deficient rats ate only 11 p. 100 of the $\mathrm{N}$ ingested by the reference lot. Moreover, that $\mathrm{N}$ was supplied by plant protein of low biological value, being particularly poor in lysine. The deficient $\mathrm{N}$-supply caused the pool of amino acids available for protein synthesis to decrease. The effect was immediate since disorders in the functions of the pancreas appeared within $24 \mathrm{~h}$ in spite of the endogenous labile protein supply. On refeeding, protein anabolism increased considerably, as clearly shown by the nitrogen 

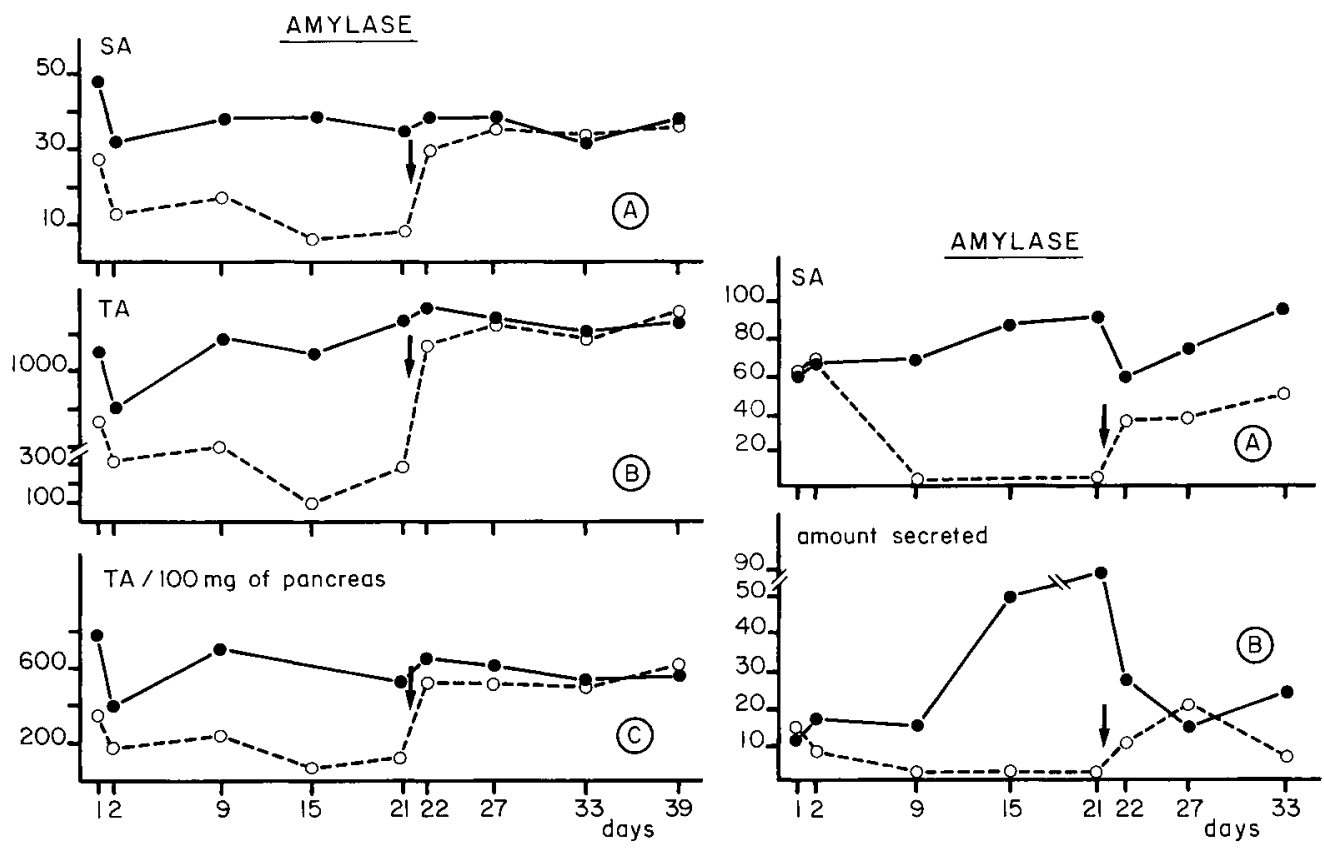

FIG. 13. - Pancreatic amylase octivity (legend fig. 5).

FIG. 14. - Pancreatic juice amylase activity (legend fig. 6).

balance : it rose from 5.4 p. 100 at the end of malnutrition to 67 p. 100 at the beginning of refeeding. The CDU increased from 66 to 88 p. 100 during the same periods.

The low DNA content of the deficient pancreas shows that pancreatic mitotic ability was affected by protein deficiency. However, the DNA and RNA/100 mg of pancreas demonstrates that in both lots of rats the number of cells per unit of organ weight and their RNA content were similar. On the contrary, the quantity of protein $/ 100 \mathrm{mg}$ of pancreas was less in deficient rats, indicating that the protein content of the pancreatic cells decreased during malnutrition. The two factors causing a decrease in deficient pancreas weight may thus be defined as (i) a change in mitotic ability, and (ii) a decrease in cellular protein content.

The rapid return to normal of the pancreatic protein content of refed rats shows that malnutrition did not irreversibly change the biochemical processes of protein syn. thesis, and that the main inhibition factor was amino acid deficiency. When sufficient protein was supplied again, protein synthesis increased more in the refed rats than in the controls.

It is now well established that when bile and pancreatic juice are continuously sampled in the rat, without being reintroduced into the intestinal aperture, the amount of bile secreted lessens with time whereas that of the juice increases. This point will be discussed later.

In addition, as our animals could not absorb any more food, they were fasted. Thus, the amounts secreted that we measured are certainly different from those of the 
intact animal and do not correspond to physiological reality. They can, however, be compared in the reference animals and in the deficient and refed ones, treated in the same way apart from the nutritional parameter.

The decrease in the amounts of bile and pancreatic juice secreted can be attributed merely to a halt in growth and to disturbances in the working of the liver and the pancreas, caused by protein malnutrition, and thus to the deterioration of the duodenal mucous membrane. These changes may decrease basal duodenal hormone (CCK-PZ, secretin, somatostatin) secretion which plays a major role in regulating the amounts of bile and pancreatic juice secretion. However, the drop in the amount of juice secreted, reported by Lemire and Iber (1967) in rats and by Descos, Duclieu and Minaire (1977) in humans, is not a constant process because Barbezat (1967), Tandon ef al. (1969) and Pitchumoni (1973) found no variation in the amount secreted in man during protein deficiency. These differences may arise from the intensity and duration of malnutrition.

We think that enzyme activities in the juice and the gland can be compared in spite of the problems involved.

Because of the rapidity of sampling, the homogenates of the pancreas should have the same enzymatic composition as that of the glands in situ. As our animals were fasted for one night before they were sacrificed, the enzyme activities measured correspond to those of a non-stimulated pancreas. Conditions were different for the juice : as the assays needed a certain volume of juice, and as malnutrition decreased the amount secreted, we were obliged to collect it over $48 \mathrm{~h}$. To find out what happened during that period, we carried out a complementary experiment which consisted of diverting the juice for $48 \mathrm{~h}$ in six $300 \mathrm{~g}$ rats which had been fed on the reference diet. The animals were in exactly the same sampling conditions as during the nutrition experiment. The juice was collected every 2 to $3 \mathrm{hrs}$ during the 48-hr period. The amount of juice secreted increased from $0.475 \mathrm{ml} / \mathrm{h}$ three hours after surgery to $0.57 \mathrm{ml} / \mathrm{h}$ after $24 \mathrm{hrs}$ and then dropped to $0.4 \mathrm{ml} / \mathrm{h}$ at the end of the $48-\mathrm{hr}$ period (average : $0.464 \mathrm{ml} / \mathrm{h}$ ). Therefore, we think that, as secretion was reduced in the beginning by surgical shock, then stimulated and finally reduced again after $24 \mathrm{~h}$, the $48-\mathrm{hr}$ average used in this study must approximate the basal liquid secretion of the rat.

During the same period, the protein content of the juice decreased from $22 \mathrm{mg} / \mathrm{ml}$ three hrs after the operation to $19.7 \mathrm{mg} / \mathrm{ml} 24 \mathrm{~h}$ afterwards, to $21 \mathrm{mg} / \mathrm{ml}$ at the end of the $48 \mathrm{hrs}$ (average : $19.9 \mathrm{mg} / \mathrm{ml}$ ). Moreover, there was a frequent opposite correlation between the protein content of the juice and the amount secreted. The amount of protein secreted in the juice varied from $10.5 \mathrm{mg} / \mathrm{h}$ three hours after surgery to $11.25 \mathrm{mg} / \mathrm{h}$ $24 \mathrm{hrs}$ afterwards, then dropped to $8.4 \mathrm{mg} / \mathrm{h}$ at the end of $48 \mathrm{hrs}$ (average : $9 \mathrm{mg} / \mathrm{h}$ ). The average amount of protein secretion found over $48 \mathrm{~h}$ in our experiment thus appears to represent the amount of protein secretion of non-stimulated juice.

If we consider that the greater part of the juice protein is composed of digestive enzymes, it would seem that in our experimental conditions, there was a certain constancy in the amount of the secreted substances we wished to measure.

However, that does not mean that the amount of each enzyme secreted was not modified. The constancy might result from the reduction of certain enzymes and the parallel increase of others. The work of Ben Abdeljlil and Desnuelle (1964) clarifies this point : «After a $10 \mathrm{~h}$ pause, no doubt caused by the shock following the operation, the 
amounts secreted of proteins, amylase and chymotrypsin reach values which are more or less constant for about $50 \mathrm{~h}$ », and our results support it.

In addition, the ratio : SA in the pancreas/SA in the juice approximates that of the rats of Ben Abdeljlil and Desnuelle (1964) which were fed on a 15 p. 100 casein diet and the rats of our reference lot which were given a 23 p. 100 mixed protein diet. The respective figures obtained are : 0.5 and 0.48 for amylase, 0.42 and 0.46 for chymotrypsin, 0.4 and 0.36 for trypsin, 0.7 and 0.69 for lipase. Yet, the former authors collected juice over $25 \mathrm{~h}$ and we over $48 \mathrm{~h}$.

All these data indicate that the juice we collected over $48 \mathrm{~h}$ corresponds to a nonstimulated secretion occurring in the rat out of the digestive phases. As the pancreas was studied in the same nutrition conditions, the enzyme activities of the gland and its external secretion can be compared cautiously.

The data on enzymes gave the expected results : a decrease in pancreatic activities and in the amount of enzymes secreted in the juice. Specific activities also declined in the pancreas as well as in its exocrine secretion, indicating that the relative value of digestive enzymes in the total protein decreased. This confirms the work of Vandermeers ef al. (1968).

A result which Vandermeers ef al. (1968) did not note, but which we found, is that the enzyme activity the most affected was that in the pancreatic juice. The non-parallelism between the activities of the pancreas and the juice indicate not only that enzyme synthesis was disturbed, but that there were changes in enzyme export by pancreatic acinous cells. This result is only true for the juice secretion obtained in our experimental conditions. It is quite possible that it is different under dietary stimulation.

Moreover, the intensity of these disorders varied with the enzyme. During malnutrition, lipase, trypsin, phospholipase $A_{2}$, chymotrypsin and amylase activities in the pancreas were affected in increasing order of magnitude ; in the juice, trypsin, chymotrypsin, lipase, phospholipase $A_{2}$ and amylase also changed in that order.

During balanced refeeding, some pancreatic enzyme activities increased to higher values than those of the reference lot (chymotrypsin, phospholipase $A_{2}$, lipase) ; others remained low (amylase, trypsin). This was also true in the pancreatic juice: whereas trypsin and chymotrypsin activities rose more than the reference values, lipase, phospholipase $A_{2}$ and amylase activities remained low.

These differences in response to malnutrition or to refeeding are due to the fact that each enzyme has its own synthesis route and a different amino acid composition, and also that its relative content in the juice or pancreas, even in normal conditions, is very different (Vandermeers, 1968). It is therefore not surprising that amylase, usually the most abundant pancreatic enzyme, was also the most affected because it needs more amino acids for synthesis.

If, in normal conditions, the pancreas produces 10 times more digestive enzymes than it needs to function (Meldolesi, 1976), the decline in juice amylase activity must be the factor exacerbating malnutrition since the low-protein diet was very rich in carbohydrates. However, we observed no digestive disorders or diarrhea, probably indicating that when dietary stimuli were present, amylase activity was greater in the juice of deficient rats. Moreover, although pancreatic amylase can adapt to the amount of sugar in the diet, our work shows that this adaptation can only take place when the protein supply is adequate. 
On the contrary, the decrease in trypsin and chymotrypsin activities did not seem to exacerbate protein malnutrition since the digestibility of cereal protein by deficient rats appeared to be normal.

Another interesting fact, confirming the results of Vandermeers, VandermeersPiret and Christophe (1967b), is the extreme sensitivity of pancreatic digestive enzymes to dietary $\mathrm{N}$-supply. We showed that malnutrition or refeeding has a most spectular effect on enzyme activities in the first 24 or $48 \mathrm{~h}$. The beneficial effects of refeeding are less clear for the juice than for the pancreas in our experimental conditions. Moreover, the improvements noted from the beginning of refeeding did not always signify a return to normal which seems to be much slower, as shown by pancreatic trypsin activity curves and those for juice amylase, phospholipase $A_{2}$ and lipase.

Reçu en novembre 1980.

Accepté en mai 1981.

Résumé. L'objet de ce travail est d'étudier, chez le rat, l'influence d'un régime de malnutrition protéique (MP) ( 3 p. 100 de protéines de céréales) et d'une réalimentation équilibrée (RE) (23,5 p. 100 de protéines mixtes) sur les activités et les débits de quelques enzymes digestives pancréatiques. Les études sont menées parallèlement sur le pancréas el sur sa sécrétion externe.

1) Lors de la MP (durée 21 jours), les débits de bile et de suc pancréatique diminuent. Durant la RE (18 jours), le débif de bile revient à la normale ef celui de suc, tout en augmentant, reste inférieur à celui des témoins.

2) La MP entraîne une légère diminution du poids du corps et du pancréas, mais surtout arrête leur croissance. La teneur en protéines et le pouvoir mitotique de la glande pancréatique diminuent. Cependant, lors de la RE, la récupération pondérale du pancréas est plus rapide que celle de l'ensemble de l'organisme. On observe aussi une augmentation de la teneur en protéines et du pouvoir mitotique de la glande.

3) La MP produit une diminution globale des activités enzymatiques, aussi bien dans la glande que dans le suc. Cependant, en l'absence de stimulation digestive, ses activités ne sont pas atteintes proportionnellement de la même façon dans le pancréas et sa sécrétion externe. Néanmoins, il n'existe pas de perturbation significative dans la digestion et l'absorption de la ration.

4) Pendant la RE, les activités enzymatiques remontent dans le suc et le pancréas, mais à des niveaux différents et, après 18 jours, la récupération n'est pas totale pour toutes les enzymes.

5) Les variations des activités enzymatiques sont particulièrement importantes pendant les 1 res $48 \mathrm{~h}$ de la malnutrition et les 1 res $36 \mathrm{~h}$ de la réalimentation.

\section{References}

BARBEZAT G. O., 1967. The exocrine pancreas and protein-calorie malnutrition. S. Afr. med.J., 41, 84.

BEN ABDELJLIL A., DESNUELLE P., 1964. Sur l'adaptation des enzymes exocrines du pancréas à la composition du régime. Biochim. biophys. Acta, 81, 136-149.

BORGSTRÖM B., HILDEBRAND H., 1975. Lipase and colipase activities of human small intestinal contents after a liquid test meal. Scand. J. Gastroent., 10, 585-591.

COLWELL A. R., 1951. Collection of pancreatic juice from rats and consequences of its continued loss. Am. J. Physiol., 164, 812-821.

DANUS O. V., URBINA A. M., VALENZUELA I., SOLIMANO G., 1970. The effect of refeeding on pancreatic exocrine function in marasmic infants. Trop. Pediatrics, 77, 334-337. 
DE HAAS G. H., POSTEMA N. M., NIEUWENHUIZEN W., VAN DEENEN L. L. M., $1968 . \quad$ Purification and properties of phospholipase A from porcine pancreas. Biochim. biophys. Acta, 159, 103-117.

DESCOS L., DUCLIEU.J., MINAIRE Y., 1977. Exocrine pancreatic insufficiency and primitive malnutrition. Digestion, 15, 90-95.

FIGARELLA C., TAULIER J., SARLES H., 1965. Dosage de la chymotrypsine et de la trypsine dans le suc duodénal. Bull. Soc. chim. Biol., 47, 679-686.

GOMEZ F., RAMOS G. R., CRAVIOTO J., FRENK S., 1954. Studies on the undernourished child. $X I$. Enzymatic activity of the duodenal contents in children affected with third-degree malnutrition. Pediatrics, 13, 544-552.

HEARD C. R., FRANGI S. M., WRIGHT P. M., 1977. Biochemical characteristics of different forms of protein-energy malnutrition : an experimental model using young rats. Br. J. Nutr., 37, 1-21.

KOPEC Z., BUCKO A., BABALA J., 1972. Effect of diet on the function and morphology of the pancreas. $X$. Effect of low-protein diet on the function and morphology of rat pancreas. Cesk. Gastroent. Vyz., 26, 1337.

LEMIRE S., IBER F. L., 1967. Pancreatic secretion in rats with protein malnutrition. Johns Hopkins med. J., 120, 21-25.

LOWRY O. H., ROSENBROUGHN. J., FARR A. L., RANDALL R. J., 1951. Protein measurement with the Folin phenol reagent. J. biol. Chem., 193, 265-275.

LYMAN R. L., WILCOX S. S., 1963. Effect of acute amino-acid deficiencies on carcass composition and pancreatic function in the force-fed rat. I. Deficiencies of histidine, methionine, phenylalamine and threonine. J. Nutr., 79, 28-36. II. Deficiencies of valine, lysine, tryptophane leucine and isoleucine. J. Nutr., 79, 37-44.

MELDOLESI J., 1976. Regulation of pancreatic exocrine secretion. Pharm. Res. Commun., 8, 1-24.

METAIS P., BIETH J., 1968. Détermination de l' $\alpha$-amylase par une microtechnique. Ann. Biol. clin., 26, 133-142.

MUNRO H. N., FLECK A., 1966. Recent developments in the measurement of nucleic acids in biological materials. Analyst, 91, 78-88.

PITCHUMONI C. S., 1973. Pancreas in primary malnutrition disorders. Am. J. clin. Nufr., 26, $374-379$.

REBOUD J. P., BEN-ABDELJLIL A., DESNUELLE P., 1962. Variations de la teneur en enzymes du pancréas de rat en fonction de la composition des régimes. Biochim. biophys. Acta, 58, 326-337.

ROBBERECHT P., VANDERMEERS A., KHAYAT M. H., RATHE J., CHRISTOPHE J., 1967. Synthèse et excrétion des hydrolases pancréatiques chez le rat dont la malnutrition protidique prend fin. Bull. Soc. chim. Biol., 49, 1735-1750.

SVOBODA D., GRADY H., HIGGINSON J., 1966. The effects of chronic protein deficiency in rats. II. Biochemical and ultrastructural changes. Lab. Invest., 15, 731-749.

TANDON B. N., GEORGE P. K., SAMA S. K., RAMACHANDRAN K., GANDHI P. C., 1969. Exocrine pancreatic function in protein calorie malnutrition disease of adults. Am. J. clin. Nutr., 22, 1476-1482.

VANDERMEERS A., CHRISTOPHE J., 1964. Influence d'une carence en lysine sur le pancréas du rat. Arch. int. Physiol. Biochim., 72, 701-703.

VANDERMEERS A., ROBBERECHT P., RATHE J., CHRISTOPHE J., 1966. Influence d'une carence en lysine sur le contenu en hydrolases du pancréas et de l'intestin grêle de rat. Bull. Soc. Chim. biol., 48, 133-153.

VANDERMEERS A., KHAYAT M. H., RATHE J., CHRISTOPHE J., 1967a. Effets d'une carence en lysine et thréonine sur le «turn over » de cinq enzymes exocrines du pancréas de rat. Arch. int. Physiol. Biochim., 75, 900-902.

VANDERMEERS A., VANDERMEERS-PIRET M. C., CHRISTOPHE J., 1967b. Synthèses protéiques in vivo dans le pancréas ef le foie du rat normal carencé en lysine et en thréonine ou récupérant de cette carence. Bull. Soc. Chim. biol., 49, 759-778.

VANDERMEERS A., KHAYAT M. H., RATHE J., CHRISTOPHE J., 1968. Vies moyennes de cinq hydrolases dans le pancréas du rat normal ou en malnutrition protéique. Biochim. biophys. Acta, 158, 448-455.

WATSON R. R., TYE J. G., MC MURRAY D. N., REYES M. A., 1977. Pancreatic and salivary amylase activity in undernourished Colombian children. Am. J. clin. Nutr., 30, 599-604. 